\title{
Úvodník Bedrníku 2013/4
}

\section{Hana Kolářová}

Envigogika 8 (5) - Informace/Information

Publikováno/Published: 31. 12. 2013

DOI: http://dx.doi.org/10.14712/18023061.422

Vážené čtenářky, vážení, čtenáři,

LOW-TECH MŮŽE BÝT KLIDNĚ HI-TECH - pohráváme si v tomto Bedrníku s pojetím nejlepších, ekologicky šetrných technologií/technik. Existuje mezinárodní "zásobník" výrobních postupů a zařízení, která se považují za nejšetrnější k životnímu prostředí, a tedy k lidem. Tyto techniky (Best Available Techniques - BAT) popisují oborové referenční dokumenty (Reference Documents on Best Available Techniques - BREF), které jsou veřejně dostupné i v češtině a nabízejí zajímavý vhled do různých výrobních oborů. Tvoří jádro Evropskou unií i Českou republikou uzákoněného procesu integrované prevence a omezování znečištění (Integrated Pollution Prevention and Control - IPPC). Nese výhody jak veřejnosti, tak výrobcům. Občané se díky ní němu seznámit s průmyslovými technologiemi, včetně zemědělské velkovýroby či třeba zpracování odpadů, které se vlastníci podniků chystají zavést. Dokonce veřejnost má za jistých podmínek možnost iniciovat přezkoumání, zda již fungující provozy z hlediska ochrany prostředí nezastaraly. Zjednodušený postup, jak se jako učitelé, žáci, občané účinně věnovat případným problémům nedaleké výrobny, najdete $v$ rubrice Proměny. Výhody přinesla integrovaná prevence znečištění i vlastníkům podniků. Jednak mohou získávat srovnání technologií z hlediska ochrany prostředí, vsadit na modernější přístupy, a tím ušetřit. Především se jim ale úřední proces povolování výroby zjednodušil.

Nejlepšími technologiemi však nemusí být vždy nejsložitější, počítačově řízené provozy. Někdy lidem stejně dobře a za menších, nejen ekologických, nákladů poslouží jednoduché, dávno objevené postupy nebo jejich kombinace s pokročilými materiály. Taková v zásadě prostá řešení - low tech či též lo-tech jako protiklad pojmu hi-tech - systematicky mapuje internetový Low-tech Magazine, v němž se například dovíte, že: elektrický velomobil je stejně rychlý a pohodlný jako auto, ale osmdesátkát účinnější; městské větrné mikroelektrárny se zatím nevyplatí; je výhodné izolovat nejprve tělo, a pak teprve dům...

V didaktické části najdete konkretizaci tématu tohoto Bedrníku v oboru, který je nám blízký z každodenního života: oblékání. Nabízíme návody, jak se zabývat ve výuce textilem a textilním průmyslem, ale je tu i moderní ekopedagogickou teorií podložený článek o tom, jak učit o šetrných technologiích. V rubrice Inspirace si přečtěte o nevšedním vzdělávacím programu Strážci Země, původem ze Spojených států, nyní uzpůsobeném pro české podmínky. Seznámit se můžete také s alchymií keramické pece vytápěné dřevem či se zajímavým výtvarným uchopením tematiky recyklace. 
Vážené čtenářky, vážení čtenáři, na předposlední straně tohoto čísla jsme pro vás připravili přehled všech 63 dosud vydaných témat Bedrníku, který už plných 11 let pomáhá vaší pedagogické práci. Čtyřiašedesátým tématem budou na počátku roku 2014: ŠKOLNÍ VÝLETY.

Radostné Vánoce, svátky prostých a hlubokých tradic, vyšperkované třeba nějakou př́rodě přátelskou technickou modernitou přeje

Hanka Kolářová

Časopis pro ekogramotnost Bedrník vydává SSEV Pavučina ve spolupráci se Střediskem ekologické výchovy a etiky Rýchory - SEVER 